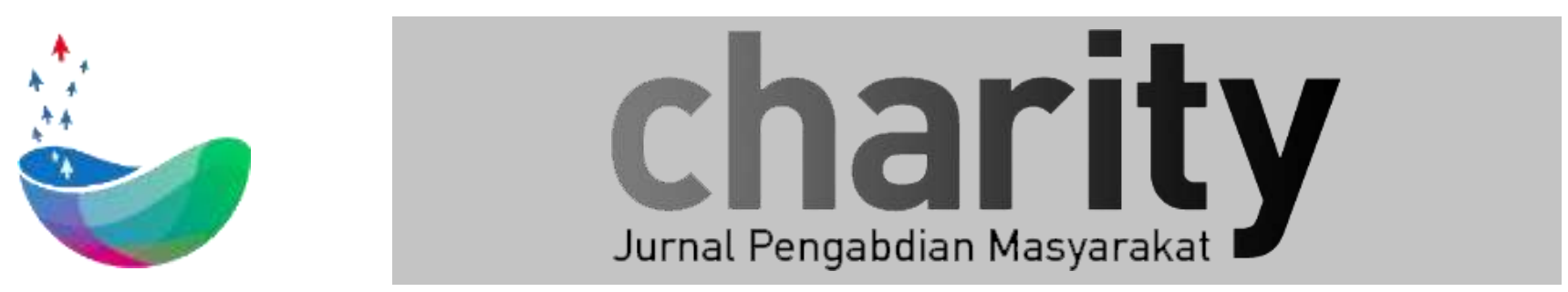

\title{
VILLAGE RESOURCE MANAGEMENT SYSTEM UNTUK MENDUKUNG TATA KELOLA DESA SUNDAWENANG, SUKABUMI, JAWA BARAT
}

\author{
Kemas Muslim L ${ }^{1}$, Eko Darwiyanto ${ }^{2}$, Dana S. Kusumo ${ }^{3}$ \\ ${ }^{1}$ Univerisitas Telkom Bandung \\ ${ }^{2}$ Univerisitas Telkom Bandung \\ ${ }^{3}$ Univerisitas Telkom Bandung \\ *kemasmuslim@telkomuniversity.ac.id
}

INFO ARTIKEL

Diterima 2 November 2017

Direvisi 8 November 2017

Disetujui 16 November 2017

Tersedia Online 24 Oktober 2018

\begin{abstract}
ABSTRAK
Desa Sundawenang di Kabupaten Sukabumi, Jawa Barat, merupakan desa yang memiliki banyak potensi, antara lain posisi yang strategis di jalan raya Sukabumi-Bogor, produksi singkong, dan terdapat sejumlah industri seperti pabrik otomotif, elektronik, boneka, wig, dan sebagainya. Kondisi desa tersebut mengundang sejumlah besar pendatang, sehingga diperkirakan $40 \%$ penduduk desa bukanlah penduduk asli setempat. Tersebarnya sejumlah industri di wilayah Desa Sundawenang juga berpengaruh terhadap mata pencaharian warga. Tercatat sebanyak $41 \%$ warga berprofesi sebagai karyawan, kemudian disusul dengan wiraswasta dan jasa (28\%), petani (27\%), dan PNS (4\%). Dengan karakteristik tersebut, Kepala Desa Sundawenang yang baru menjabat pertama kali memerlukan data dan berbagai laporan untuk menyusun berbagai program dan kebijakan desa yang sesuai. Village resource management system (VRMS) dibangun untuk memberikan solusi bagi kebutuhan Kepala Desa tersebut. VRMS terdiri dari tiga aplikasi utama, yaitu aplikasi pelayanan desa, aplikasi pengelolaan data desa, dan aplikasi analisis data. Aplikasi pelayanan desa telah diresmikan dan diberikan pelatihan penggunaannya kepada aparat Desa Sundawenang. Diharapkan aplikasi ini dapat diterapkan pada desa-desa lain di Indonesia dengan penyesuaian yang dapat dilakukan untuk mengakomodasi kebutuhan yg lebih khusus.
\end{abstract}

Keyword : VRMS, Desa

Korespondensi :

Direktorat Penelitian dan Pengabdian Masyarakat, Universitas Telkom

J1. Telekomunikasi No. 1, Terusan Buah Batu, Bandung, 40257

Indonesia.

E-mail: charity@telkomuniversity.ac.id

ORCID ID:

Penulis Pertama: -

https://doi.org/10.25124/charity.v1i01.1586

Paper_reg_number Charity0011010111 @ The Authors. Published by Directorate of Research and Community

Service, Telkom University.

This is an open access article under the CC BY-NC 4.0 license (https://creativecommons.org/licenses/by-nc/4.0/) 


\section{RUMUSAN MASALAH}

Desa Sundawenang terletak di kecamatan Parungkuda kabupaten Sukabumi Jawa Barat. Desa ini berjarak $25 \mathrm{~km}$ dari kota Sukabumi. Desa Sundawenang berada dijalan raya yang menghubungkan Sukabumi dan kota Bogor (Gambar 1).

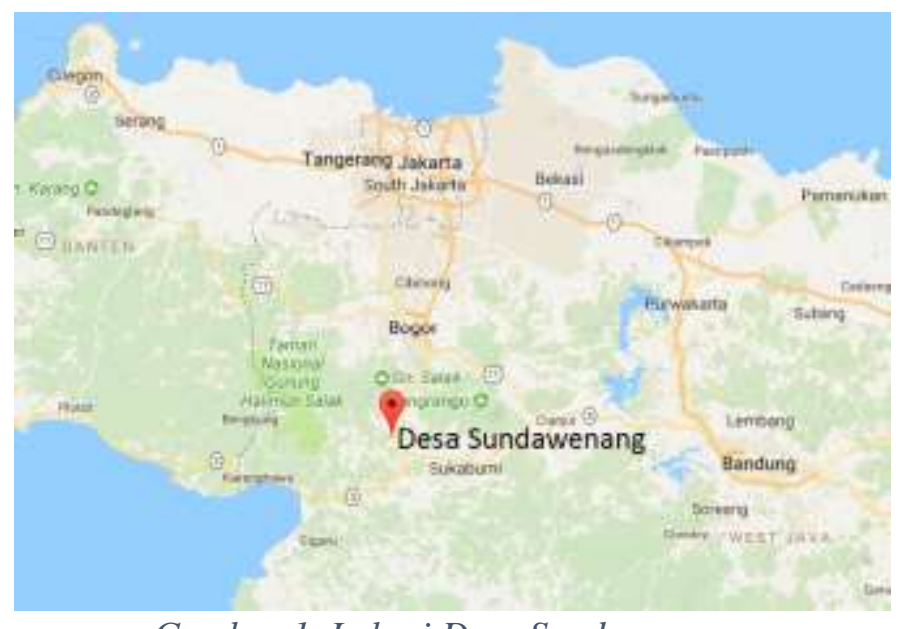

Gambar 1. Lokasi Desa Sundawenang.

Karena terletak pada jalan raya Sukabumi-Bogor, banyak pabrik-pabrik besar yang berdiri di desa Sundawenang, antara lain otomotif (NTP/Yamaha), elektronik (Starcomgistic), garment (Pandu Dewanata, DSS, Young Huan Star, Baju Indah, dll), wig/rambut palsu (Nina Venus Indonesia), Boneka (Royal Puspita, Alpha Toys, dll), dan farmasi (Promedrahardjo Pharmacy Industry). Keberadaan berbagai industri di wilayah Desa Sundawenang membentuk persentase profesi penduduknya, seperti yang terlihat pada Gambar 2, sehingga memunculkan tantangan dan permasalahan yang khas dibandingkan dengan desa lainnya. Profesi warga Desa Sundawenang yang sebagian besar $(41 \%)$ adalah karyawan pabrik menyebabkan tantangan tersendiri dalam mewujudkan pelayanan warga. Karena terikat dengan jam kerja, buruh pabrik yang memerlukan pelayanan desa untuk berbagai keperluan sering kali merasa kesulitan untuk meluangkan waktu dan berkunjung ke kantor desa. Berbeda dengan desa-desa lain yang berbasis pertanian, hanya $27 \%$ warga yang berprofesi sebagai petani, sedangkan $28 \%$ berprofesi di bidang wiraswasta dan jasa. Hanya sebagian kecil saja (4\%) warga yang berprofesi sebagai PNS.

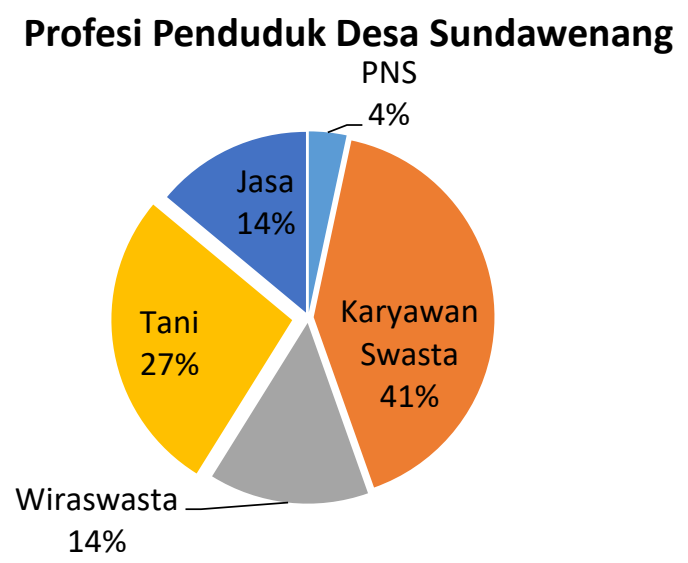

Gambar 2. Profesi penduduk Desa Sundawenang.

Untuk menyusun berbagai kebijakan dan program pembangunan desa yang tepat berdasarkan karakteristik dan permasalahan yang ada, Kepala Desa Sundawenang yang baru saja menjabat pertama kali, Wahid, S.IP, memerlukan data yang rinci, akurat, dan sistem pendukung keputusan. Sebagai Kepala Desa yang baru, ketersediaan data dalam format digital yang siap diolah merupakan hal yang sangat penting. Untuk memenuhi keperluan tersebut, 
Kepala Desa Sundawenang memerlukan sistem informasi yang dapat mendukung pengelolaan data di desa tersebut. Ketidaktersediaan sistem informasi juga mengakibatkan kesulitan dalam menyusun berbagai macam laporan yang diperlukan oleh Kepala Desa maupun institusi di atasnya. Hal ini dapat berujung kepada kesulitan dalam merealisasikan dana desa yang disediakan pemerintah pusat.

Berdasarkan analisis kondisi di atas, permasalahan yang dialami oleh Kepala Desa beserta jajaran aparat Desa Sundawenang adalah sebagai berikut:

1. Sulitnya pekerja pabrik untuk mengunjungi kantor desa dan mendapatkan layanan desa karena terikat dengan jam kerja.

2. Miskinnya data yang dimiliki mengenai penduduk dan sumber daya desa.

3. Tidak adanya sistem yang memungkinkan aparat desa untuk mengelola data.

4. Kesulitan dalam menyusun berbagai macam laporan yang diperlukan oleh Kepala Desa dan institusi pemerintahan lainnya.

Untuk memberikan solusi terhadap berbagai permasalahan dan tantangan di atas, Kepala Desa dan tim PkM membangun village resource management system (VRMS), yaitu sistem informasi yang mengelola data sumber daya desa untuk mendukung tata kelola pemerintahan Desa Sundawenang. Sesuai dengan rumusan masalah di atas, peta jalan pembangunan VRMS meliputi tiga aplikasi utama, yaitu aplikasi pelayanan desa, aplikasi pengelolaan data desa, dan aplikasi analisis data (Gambar 3), masing-masing dibangun dalam 1 tahun. Pembangunan aplikasi layanan desa telah selesai dilakukan, dan telah diluncurkan dan diadakan pelatihan.

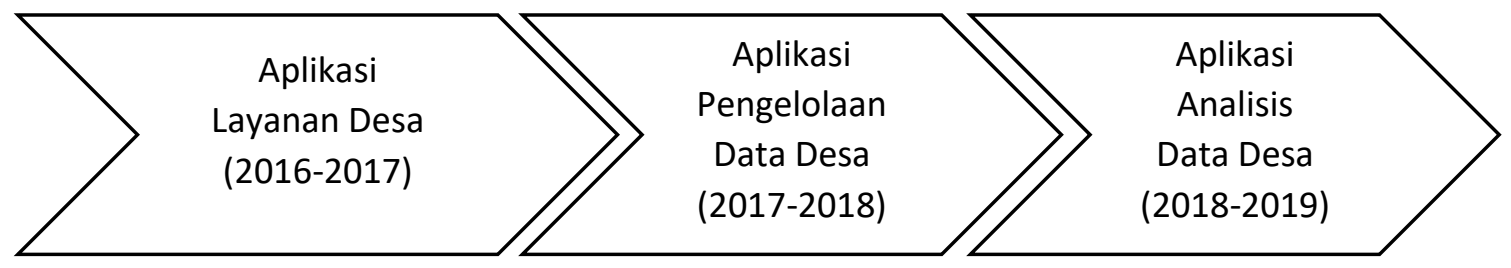

Gambar 3. Peta jalan pembangunan aplikasi village resource management system (VRMS).

\section{METODE PELAKSANAAN PENGABDIAN MASYARAKAT}

Pembangunan sistem informasi VRMS dilaksanakan dalam beberapa tahapan sebagai berikut:

1. Analisis kebutuhan sistem

Pada tahapan ini, kami mengidentifikasi kebutuhan pengguna terhadap sistem informasi yang akan dibangun. Metode yang kami gunakan adalah wawancara dan pengumpulan berbagai macam laporan yang dibutuhkan oleh Kepala Desa dan jajarannya. Keluaran dari tahapan ini adalah daftar fungsionalitas dan rancangan awal basis data yang akan dibangun.

2. Perancangan

Sistem informasi VRMS dirancang berdasarkan hasil analisis kebutuhan sistem. Tahapan ini menghasilkan berbagai macam rancangan, antara lain rancangan akhir basis data, rancangan proses, dan rancangan antar muka sistem.

3. Implementasi purwarupa (prototype)

Rancangan sistem informasi VRMS yang dihasilkan pada tahapan sebelumnya sudah siap diimplementasikan oleh pemrogram. Pada tahap ini, dibangun VRMS versi yang sederhana sebagai purwarupa dari VRMS yang sesungguhnya.

5. Pengujian purwarupa

Maksud dari pembangunan purwarupa adalah untuk mendapatkan umpan balik dari pengguna mengenai sistem informasi VRMS yang dibangun. 
6. Pembangunan aplikasi

Setelah mendapatkan umban balik dari pengguna mengenai purwarupa sistem VRMS, sistem informasi VRMS yang sesungguhnya akan dibangun.

7. Pengujian dan pelatihan

Pada tahap akhir, dilakukan pengujian sistem VRMS. Apabila sistem VRMS telah berjalan, selanjutnya dilakukan pelatihan kepada para pengguna VRMS, yaitu Kepala Desa dan bawahannya.

\section{ANALISA HASIL KEGIATAN PENGABDIAN MASYARAKAT}

Aplikasi layanan desa yang dibangun merupakan hasil analisis bersama antara tim PkM dengan Kepala Desa. Aplikasi ini dibangun terlebih dahulu dibandingkan dengan aplikasi lainnya yang merupakan bagian dari VRMS (lihat Gambar 3) karena merupakan aplikasi yang paling dibutuhkan dan bersentuhan langsung dengan warga desa sehingga manfaatnya bisa langsung dirasakan secara luas. Aplikasi layanan administrasi surat warga diimplementasikan berupa aplikasi Android (Gambar 4) dan web (Gambar 5).
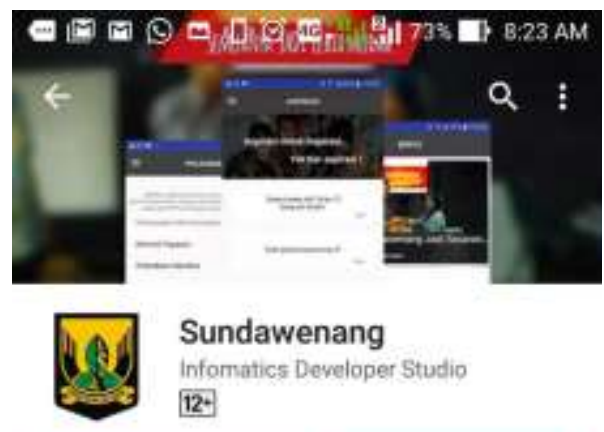

\section{Sundawenang}

Informatics Developer Studio

12.

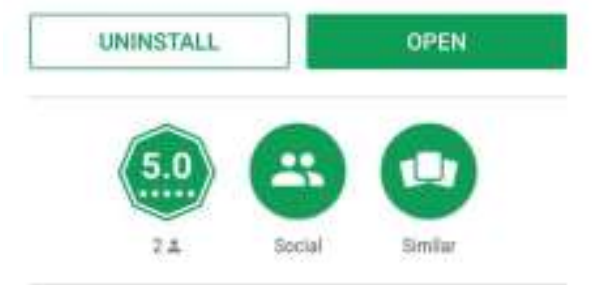

Applications to connect rural

cammunities with village officials

sundawenang

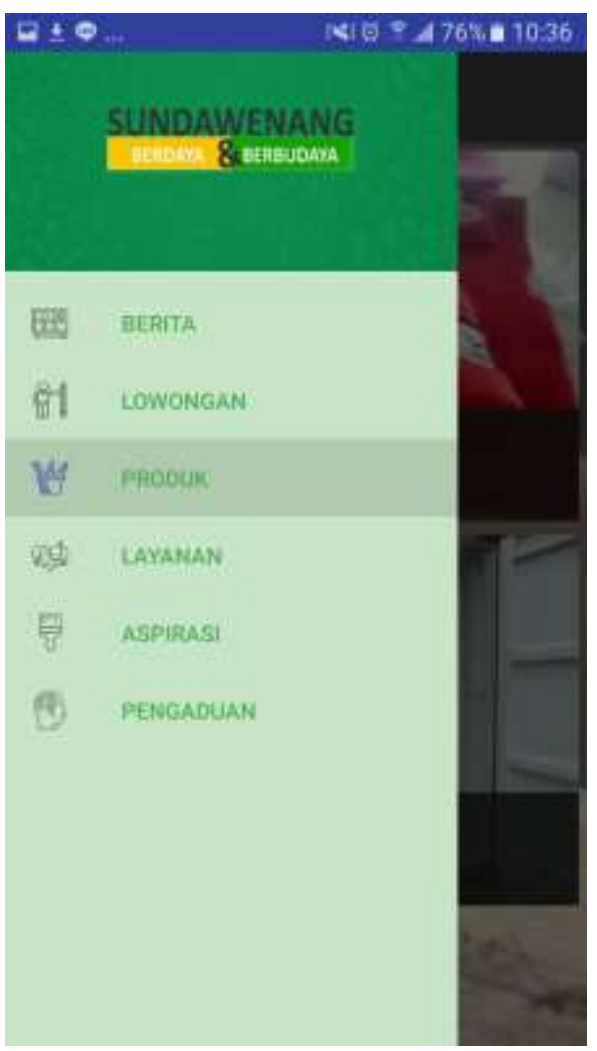

Lihat Berite

Gambar 4. Tampilan aplikasi Android untuk layanan desa VRMS.

Kiri: tampilan aplikasi pada playstore. Kanan: tampilan menu aplikasi.

Secara umum, cara kerja aplikasi ini adalah sebagai berikut:

1. Warga desa mengajukan kebutuhan administrasi desa melalui aplikasi Android dengan menyertakan bukti pembayaran PBB.

2. Pengajuan kebutuhan administrasi warga tercatat di basis data kemudian diakses oleh operator aparat desa melalui aplikasi web. Setelah identitas warga dan bukti pembayaran PBB dinyatakan valid, sesuai dengan isian yang telah dimasukan oleh warga

3. File PDF surat yang dikehendaki ditampilkan, diprint, dan Kepala Desa tinggal tanda tangan. 


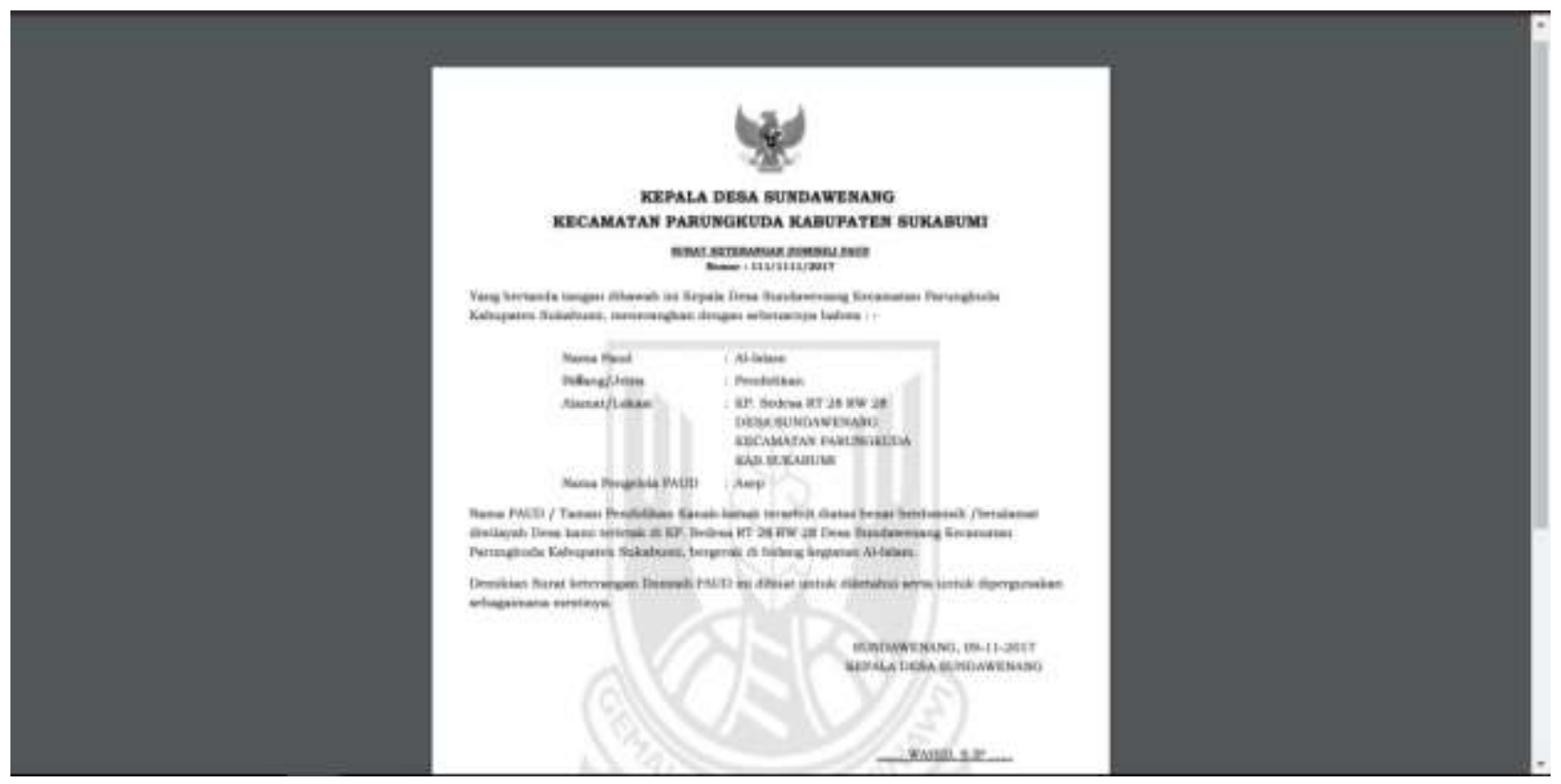

Gambar 5. Surat yang telah dibuat berdasarkan masukan dari warga melalui aplikasi android dan ditampilkan di web.

Aplikasi layanan desa dapat melayani pembuatan berbagai surat sebagai berikut:

1. Surat Keterangan Tempat Tinggal

2. Surat Keterangan Domisili PAUD

3. Surat Keterangan Domisili Yayasan

4. Surat Pengantar SKCK (Surat Keterangan Catatan Kepolisian)

5. Surat Keterangan Ijin Usaha

6. Surat Keterangan Perbedaan Identitas

7. Surat Pengantar Akta Kelahiran

8. Surat Pengantar Pernikahan

9. Surat Keterangan Penilaian Harga Objek Pajak

10. Surat Keterangan Ahli Waris

Berkat aplikasi ini, dan juga kemajuan dan terobosan lain yang dilakukan oleh Kepala Desa, Desa Sundawenang meraih Juara III Lomba Desa Kabupaten Sukabumi Tahun 2017. Di samping itu, aplikasi ini memiliki nilai strategis dalam meningkatkan partisipasi masyarakat Kabupaten Sukabumi dalam membayar PBB, yang sejauh ini baru sekitar 60-70\%.

\section{PEMBAHASAN}

Aplikasi ini telah diluncurkan oleh Kepala Desa dalam acara ulang tahun Desa Sundawenang, yang dihadiri oleh Wakil Bupati Sukabumi dan pejabat dari Kementerian Desa, Pembangunan Daerah Tertinggal, dan Transmigrasi, pada tanggal 22 Agustus 2017 (Gambar 6). Kemudian, pada tanggal 2 November 2017 dilakukan pelatihan kepada para operator aplikasi layanan desa, yang merupakan aparat Desa Sundawenang (Gambar 7). 


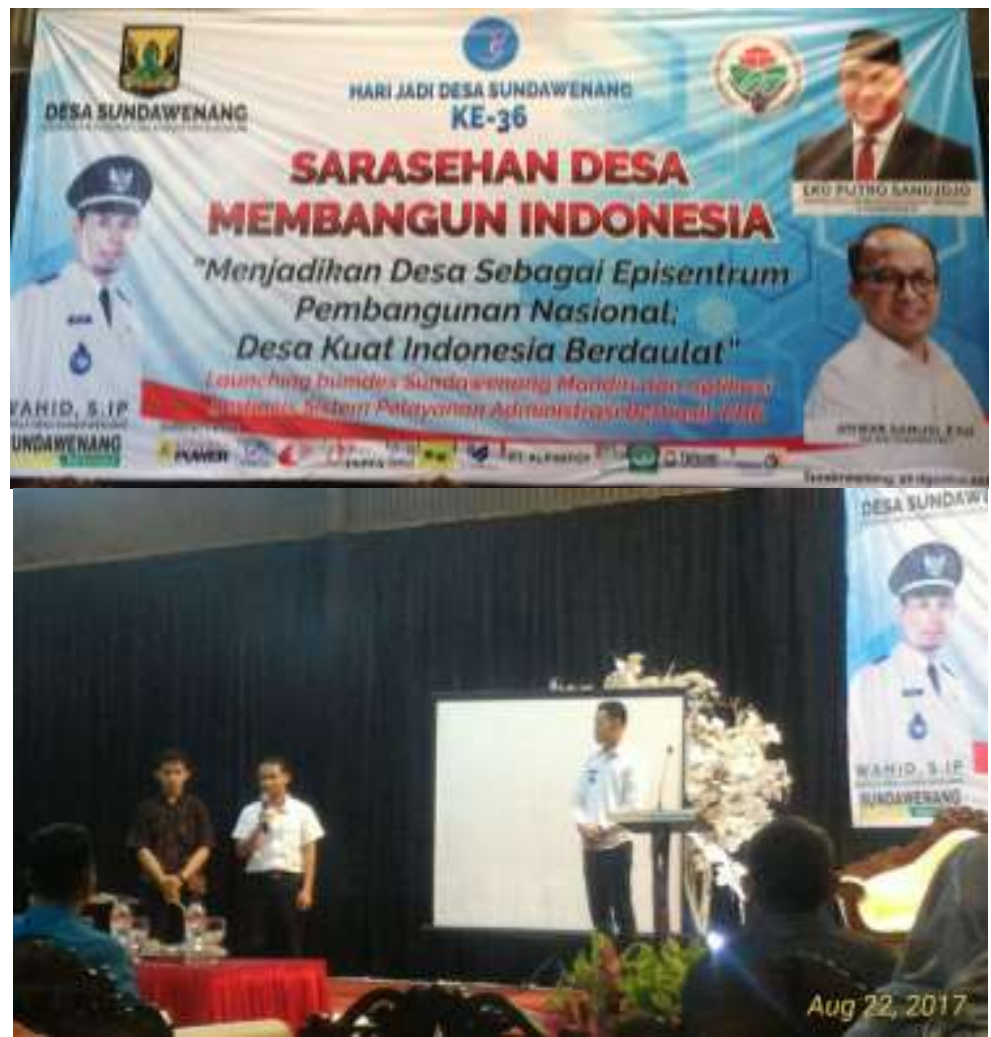

Gambar 6. Peluncuran aplikasi layanan desa VRMS pada acara ulang tahun Desa Sundawenang, 22 Agustus 2017.

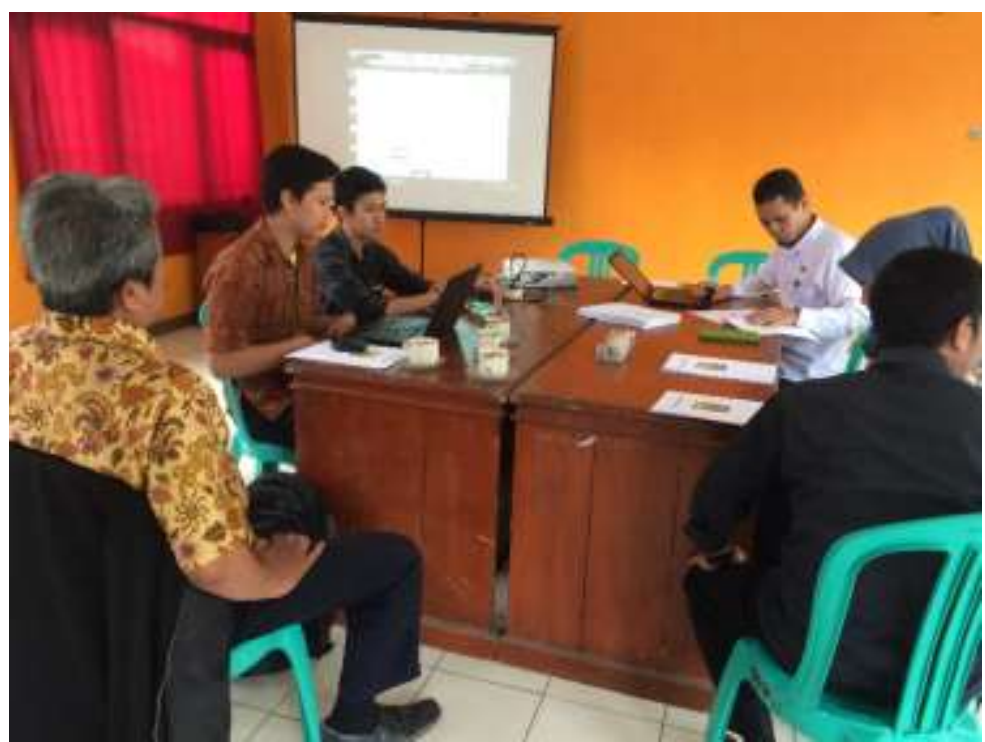

Gambar 7. Pelatihan aplikasi layanan desa VRMS pada tanggal 2 November 2017.

Pembangunan aplikasi ini berdasarkan dan menyesuaikan dengan kebutuhan sistem yang diberikan oleh aparat Desa Sundawenang, khususnya Kepala desa Sundawenang, Wahid S.IP.

Aplikasi ini membantu aparat Desa Sundawenang untuk:

1. Menyediakan sistem informasi bagi aparat desa untuk membantu proses pengumpulan dan pengelolaan data.

2. Menyediakan berbagai fungsi untuk menyusun berbagai macam laporan yang diperlukan oleh aparat desa. 
Forum Komunikasi Pemuda Sukabumi telah melihat bahwa aplikasi ini memiliki nilai yang strategis dalam tata kelola Desa Sundawenang. Dalam kunjungannya ke kampus Universitas Telkom, wakil forum komunikasi tersebut sangat antusias untuk memperkenalkan aplikasi ini ke berbagai desa di Kabupaten Sukabumi. Bahkan, aplikasi ini juga layak dipresentasikan di Kementrian Pedesaan untuk disebar di seluruh desa di Indonesia.

\section{SIMPULAN DAN SARAN}

Dalam kegiatan pengabdian kepada masyarakat dengan bantuan dana internal Universitas Telkom ini sudah dibangun aplikasi Android dan web untuk pelayanan warga desa berupa administrasi. Aplikasi layanan administrasi desa ini merupakan bagian dari VRMS yang akan senantiasa dikembangkan hingga dua tahun ke depan (total selama tiga tahun). Dua aplikasi yang akan dibangun pada tahun-tahun berikutnya adalah aplikasi pengelolaan dan analisis data desa.

Aplikasi ini telah diterima dan diresmikan oleh Kepala Desa dan telah dilatihkan kepada para aparat desa yang akan menjadi operator aplikasi tersebut. Kepala Desa menerima aplikasi dengan baik dan sangat antusias untuk senantiasa mengembangkan aplikasi ini pada tahuntahun mendatang. Aplikasi ini juga berperan penting dalam mengantarkan Desa Sundawenang untuk meraih Juara III dalam lomba antar desa di Kabupaten Sukabumi.

Kami juga berharap agar aplikasi ini dapat diterapkan secara luas untuk seluruh desa yang ada di Indonesia karena kebutuhan dan proses-proses yang ada dalam aplikasi ini telah disesuaikan dengan kebutuhan desa pada umumnya. Kedepannya, kami berharap untuk mendapatkan studi kasus yang sejenis utuk menguji dan menyesuaikan pengembangan aplikasi sehingga dapat diterapkan secara luas di desa-desa yang ada di Indonesia.

\section{IDENTITAS PENULIS}

Dr. Kemas Muslim Lhaksmana adalah dosen di Fakultas Informatika, Universitas Telkom sejak tahun 2011. Setelah mendapatkan gelar S1 dari Teknik Informatika, ITB, pada tahun 2005, ia kemudian meraih gelar S2 Information Systems Development, dari HAN University, Belanda (2009), kemudian S3 dari Department of Social Informatics, Kyoto University, Jepang (2016). Ia pernah bekerja sebagai pengembang perangkat lunak di PT. Ihsan Solusi Informatika (2005-2011). Saat ini ia juga menjabat sebagai Technology R\&D Manager di Bandung Techno Park. Bidang penelitian yang ia tekuni selama ini adalah IoT dan services computing.

Eko Darwiyanto, M.T. adalah dosen di Fakultas Informatika, Universitas Telkom. Ia merupakan lulusan S1 Teknik Informatika, ITB (1993), dan S2 Teknik dan Manajemen Industri, ITB (2000). Ia telah melakukan banyak penelitian dan pengabdian masyarakat di bidang sistem informasi dan ERP. Saat ini ia menjabat sebagai ketua kelompok keahlian Software Engineering, Information System, and Data Engineering (SIDE) di Fakultas Informatika.

Dana Sulistyo Kusumo, PhD adalah dosen di Program Studi S2 Informatika, Fakultas Informatika, Universitas Telkom sejak tahun 2002. Setelah mendapatkan gelar S1 dari Teknik Informatika, STT Telkom, pada tahun 2001, ia kemudian meraih gelar S2 Teknologi Informasi, dari ITB (2007), kemudian S3 dari School of Computer Science and Engineering, University of New South Wales, Sydney, Australia (2013). Ia pernah bekerja sebagai staff interkoneksi di PT Satelindo (2001-2002). Saat ini ia juga menjabat sebagai Ketua Program Studi S2 Teknik Informatika, Universitas Telkom. Bidang penelitian yang ia tekuni selama ini adalah Rekayasa Perangkat Lunak, Arsitektur Informasi dan User Experience. 